Joseph Ibn Nahmias. The Light of the World: Astronomy in al-Andalus. Edited, Translated, and with a Commentary by Robert G. Morrison. Oakland: University of California Press, 2016. 429 pages. ISBN: 9780520287990.

\title{
Ruth Glasner
}

The Light of the World is an astronomical book written in Arabic by the Jewish astronomer Joseph ibn Nahmias (fl. $8^{\text {th }} / 14^{\text {th }}$ cent.) and later translated into Hebrew. It is now extant in one Arabic manuscript (in Hebrew letters) and one Hebrew manuscript. Robert G. Morrison's edition is an important contribution to the field of medieval astronomy. Especially impressive is his presentation of Nahmias' work as a step in the history of homocentric astronomy. Morrison points out the advantages of Nahmias' astronomy over al-Bițrüiìs (fl. $6^{\text {th }} / 12^{\text {th }}$ century) and traces the influence of The Light of the World until the sixteenth century.

The astronomical context of The Light of the World is the incompatibility between Ptolemaic astronomy and Aristotelian physics, which was a major problem in medieval science. Aristotelian science was designed to conform to the homocentric models of Eudoxus (d. ca. 338 BC) and Callipus (d. ca. 300 BC). Shortly after these models were replaced by the astronomically better eccentric, epicyclic, and equant models, the harmony between astronomy and physics was broken. The incompatibility between these two sciences was mostly ignored (philosophers and astronomers tended to mind their own business), but from time to time the question of their incompatibility was raised and solutions were sought. One important such episode was the "Andalusian Revolt" that took place in Muslim Spain in the twelfth century. ${ }^{1}$ The main leaders were Ibn Țufayl (d. 580/1185) and, following him, al-Bițrūjī. Ibn Rushd (d. 595/1198) and Maimonides (d. 600/1204) were also involved in this intellectual exploit, but contributed more to raising questions than to undertaking any serious

\footnotetext{
* The Hebrew University of Jerusalem, Program for the History and Philosophy of Science. I am grateful to Gad Freudenthal for reading the review and for his comments.

1 A. I. Sabra, "The Andalusian Revolt against Ptolemaic Astronomy: Averroes and al-Bițrūjī," in Transformation and Tradition in the Sciences: Essays in Honor of I. Bernard Cohen, ed. Everett Mendelsohn (Cambridge \& New York: Cambridge University Press, 1984), 133-53.
} 
attempt to answer them. The supremacy of Aristotelian cosmology and physics was taken for granted, and the goal of the "revolt" was to provide a new homocentric astronomy that would be compatible with Aristotelian principles and more precise than that of Eudoxus and Callipus. The only astronomical output of the "revolt" that has come down to us is a book by al-Bitrūjì that offers new astronomical models, but instead of dealing with eccentrics and epicycles, this astronomer introduced motions around poles on the circumference of the sphere.

Al-Bițrūjī's book was translated into Hebrew and Latin, and was influential despite its many shortcomings. Whereas the Jewish astronomers Levi ben Gershom (d. 1344) in Provence and Ishaq Israeli (fl. $8^{\text {th }} / 14^{\text {th }}$ cent.) in Castile criticized al-Bițrūjī, Joseph ibn Naḥmias, as Morrison shows, was interested in his models and tried to improve upon them. Morrison skillfully points out the five innovations that made Nahmias' astronomy more successful than that of his Andalusian predecessor, and does a good job of presenting his astronomical agenda and the details of his models.

But what do we really know about Joseph ibn Nahmias? Bibliographers identify a traditional Sephardi Jewish scholar named Joseph Nahmias, who belonged to the circle of R. Asher ben Yehiel (Rosh, d. 1327), as the author of a few commentaries on the Bible and the Mishna. In 1988-89, Gad Freudenthal published a brief communication in Qiriat Sefer ${ }^{2}$ suggesting that the author of The Light of the World was a different Joseph Nahmias (presumably from the same family), who lived three generations later. He dates the book to about 1400 and adds that nothing is known about Joseph Nahmias the astronomer, except that an astrological prognostication for the year 1478/79 has been ascribed to him. ${ }^{3}$ Freudenthal's argument is convincing, and Morrison has adopted it and added some support by relying upon a letter from Don Vidal Benbeniste addressed to Joseph ibn Nahmias (5, no. 12) that confirms the dating of Nahmias to the early fifteenth century. Yet we still know next to nothing about the author of The Light of the World. Morrison associates the renewed interest in the "Andalusian Revolt," after the passage of more than two centuries, with the "resurgence of Aristotelianism" among Jews in Christian Spain in the fifteenth century (2). Provided that the book's dating is indeed correct, this suggestion is interesting and can shed some light on this late turning back to astronomical models that were not even close to being successful.

2 The paper was translated into English and printed in Gad Freudenthal, "Towards a Distinction between the Two Rabbis Joseph ibn Joseph ibn Nahmias," in Science in the Medieval Hebrew and Arabic Traditions (Aldershot: Ashgate, 2005), chapter 8. 
Morrison makes an effort - sometimes- to present this text against the background of Jewish scholarship. He remarks that "although The Light of the World did not cite a single text in Hebrew besides the Bible, there are a number of important thematic parallels between it and other texts in Hebrew" (14). In this vein, he makes several arguments. Let me address two examples.

[i] Morrison writes that “Ibn Nahmias' position on astronomy's epistemological challenges makes sense in the light of Levi ben Gerson's position in the debate over Maimonides' perplexity" (14). Furthermore, "While Ibn Nahmias did not refer to Gersonides' work, Gersonides' position that humans could increase their certain knowledge of the heavens accorded with Ibn Nahmias' view of the possibility of devising a homocentric astronomy endowed with predictive accuracy" (1415). Pointing out such general similarity is by no means sufficient. There is no convincing evidence that Nahmias was at all familiar with Gersonides' astronomy. It seems more likely that he was not. Nahmias neither argues with Gersonides' harsh criticism of al-Bițrūjī, nor does he mention this astronomer's altogether different astronomical models. The fact that Nahmias does not address Gersonides' criticism of al-Bitrūjīi is hardly surprising, for the astronomical part of Gersonides' Wars of the Lord was not readily available in the Iberian Peninsula. ${ }^{4}$ It is more likely that he was acquainted with Ishaq Israeli's Yessod 'Olam, which was composed in the Rosh's circle (and also contains a criticism of al-Biṭrūjī).

[ii] Morrison writes: "While Ibn Nahmias did not name any of these commentators [on Maimonides' Guide], the context of these commentaries and their parallels with The Light of the World show how such debates were part of Jewish intellectual life" (15). The debate on eccentric orbs and epicycles was a major issue throughout the Middle Ages. It is discussed in chapter II.24 of Maimonides' well-known Guide of the Perplexed, and naturally also of the commentaries on this chapter, but is there any definitive evidence that Nahmias read those commentaries?

Morrison's volume includes an extensive introduction, Nahmias' original Arabic text (in Hebrew letters), an English translation of the Arabic text, a Hebrew redaction of the text made in Nahmias' lifetime (perhaps by the author himself [xiii]), an English translation of "the Significant Insertions in the Hebrew Recension The Light of the World" (viz., those sections in which the Hebrew translation includes some additions to the original Arabic), commentaries on the Arabic text and the insertions in the Hebrew recension, and the Hebrew text and English translation 
of Porfiat Duran's (Efodi) response to Nahmias' treatise. The separation between the commentary on the Arabic text and the one on the insertions in the Hebrew translation (chapters 5 and 6) is inconvenient. The comments of the insertions could have been integrated in the main commentary at the end of the paragraphs that include insertions.

The text is divided into paragraphs, a division that is well done and helps the reader studying one of the texts (chapter 1-4) find the parallel paragraphs in the other three and locate the relevant commentaries (chapter 5-6). Morrison provides both the paragraph numbers and the folio numbers (emphasized in bold characters and preceded by blank lines). These latter numbers, which interrupt the text's flow and interfere with its reading, could have been marked in the margin or included in the text within brackets. Moreover, instead of being useful they are rather confusing, given that the Hebrew text (following the ms) is numbered inversely from $127 \mathrm{~b}$ to $101 \mathrm{a}$. If the commentary (chapters 5-6) had been linked to the text (chapters 1-4) by paragraph numbers, there would have been no need for providing the folio numbers at all.

In conclusion, notwithstanding the comments made above about the introduction's historical part, both the astronomical section and the astronomical commentary are clear and helpful. Most importantly, the translation is very good and reliable. ${ }^{5}$ The final result of this difficult project, which required several special skills, is a very welcome contribution to the existing research on medieval astronomy.

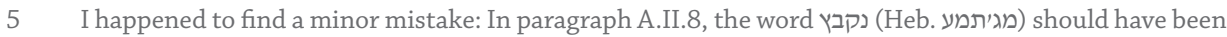
translated in this context as "multiplied" instead of "combined" (116). Abraham Bar-Hiyya used the Hebrew word for both the result of addition and of multiplication. See Gad B. Sarfatti, Mathematical Terminology in Hebrew Scientific Literature of the Middle Ages (Jerusalem: Magnes Press, 1968), 82 (in the Hebrew section). 